\title{
EFEKTIVITAS LAYANAN KONSELING KELOMPOK MELALUI TEKNIK SELF MANAGEMENT UNTUK MENINGKATKAN KEBIASAAN BELAJAR SISWA KELAS VIII SMPN 1 KAPONTORI
}

\author{
Maria Ulfa, S.Pd., M.Si. \\ Ni Komang Suarningsih \\ Universitas Muhammadiyah Buton \\ ulfa.razak88@gmail.com
}

\begin{abstract}
Abstrak
Kebiasaan belajar mulai sangat diperlukan saat manusia memasuki masa remaja karena masa remaja merupakan masa yang penuh gejolak sehingga siswa sering dihadapkan pada persoalan-persoalan yang kompleks yang menjadi permasalahan yang dirasakan sulit oleh para siswa termaksud dalam hal belajar. Dalam penelitian ini, peneliti memilih layanan konseling kelompok melalui teknik self management untuk meningkatkan kebiasaan belajar siswa. Tujuan penelitian ini untuk mengetahui dan mendeskripsikan layanan konseling kelompok melalui teknik self management untuk meningkatkan disiplin belajar siswa. Metode penelitian yang digunakan adalah pendekatan penelitian kuantitatif dengan desain penelitian kuantitatif metode eksperimen pre-experimental dengan desain One Group Pretest Posttest. Adapun populasi dalam penelitian ini adalah siswa kelas VIII SMP Negeri 1 Kapontori melalui teknik purpossive sampling dengan sampel penelitian 12 siswa.Berdasarkan hasil penelitian dan analisis data diperoleh kesimpulan: (1) secara umum, tingkat kebiasaan belajar siswa kelas VIII SMP Negeri 1 Kapontori menunjukkan bahwa 35 siswa atau 100\% subyek berada pada kategori tinggi atau memiliki kebiasaan belajar yang baik, dengan pemberian perlakuan kurang lebih delapan kali treatmen. Sehingga dapat disimpulkan bahwa pemberian perlakuan melalui teknik self management dapat meningkatkan kebiasaan belajar siswa; (2) ada perbedaan yang signifikan antara kelompok pretest dengan kelompok posttest dengan nilai masing-masing nilai sig. (2-tailed) probabilitas 0.000 pada taraf signifikansi nilai 0.05 ( $p<0.05$ ), yang berarti dapat disimpulkan bahwa layanan konseling kelompok melalui teknik self management untuk meningkatkan kebiasaan belajar siswa yang dilakukan berhasil secara signifikan atau efektif untuk dilakukan.
\end{abstract}

Kata Kunci: Konseling Kelompok; Self Management; Kebiasaan Belajar

\section{A. PENDAhULUAN}

Siswa Sekolah Menenggah Pertama (SMP) yang tergolong dalam usia remaja, mengalami proses perkembangan dan pertumbuhan serta mempunyai kecenderungan kurang stabil secara psikis. Melalui pengamatan penulis di SMP Negeri 1 Kapontori setelah mengobservasi siswa mengalami kesulitan dalam membiasakan belajarnya, sebagian siswa/siswi yang kurang perhatian dan kesungguhan saat mengikuti mata pelajaran. Kebiasaan yang kurang baik juga masih dijumpai di sebagian diri siswa/siswi. Siswa/siswi belajar hanya saat menjelang ujian atau ulangan semester bahkan tidak ada persiapan sama sekali.

Selain itu masih ada siswa/siswi yang mempunyai persepsi yang negatif terhadap metode mengajar guru sehingga mereka 
cenderung bermalas-malasan untuk mengikuti belajar mengajar di kelas akibatnya aktivitas belajarnya menurun dan prestasi yang diperolehnya kurang memuaskan. Ini di sebabkan oleh teknologi seperti HP, dimana siswa-siswi menjadi malas belajar karena waktu belajar di rumah hanya di gunakan untuk internetan seperti FB, BBM, WA, dll, sehingga mengakibatkan siswa-siswi kurangnya kebiasaan belajar dalam dirinya.

Pemberian pemahaman tentang pentingnya tujuan belajar masih sangat sulit untuk dipahami oleh siswa pada umumnya. Sehingga dibutuhkan layanan yang bisa membantu siswa dalam menyelesaikan konflik yang ada pada dirinya. Salah satunya ada pada layanan bimbingan dan konseling. Bimbingan dan Konseling memiliki tujuh layanan yang merupakan kegiatan bantuan dan tuntunan yang diberikan kepada individu pada umumnya dan siswa sekolah pada khususnya dalam rangka meningkatkan mutunya. Berdasarkan hasil pengamatan, untuk pelaksanaan layanan konseling kelompok, peneliti menggunakan teknik self management (pengelolaan diri). Teknik ini akan lebih efektif melalui pemberian layanan konseling. Karena Teknik ini merupakan teknik yang dapat merubah perilaku seseorang untuk menghilangkan kebiasaan buruk contohnya seperti: malas belajar, suka bolos, suka membuli, boros, keluar masuk saat jam pelajaran berlangsung dll. Teknik ini dimaksudkan untuk meningkatkan kepekaan klien agar mengamati respon pada stimulus yang disenanginya dengan kebalikan stimulus tersebut.Menurut Heru Mugiarso (2007) konseling kelompok merupakan layanan konseling yang diselenggarakan dalam suasana kelompok. Materi umum layanan konseling kelompok diselenggarakan dalam kelompok yang memanfaatkan dinamika kelompok yang meliputi segenap bidang bimbingan.

Dengan demikian konseling kelompok menggunakan teknik self management memberikan kontribusi yang penting dalam memotivasi siswa, apalagi masalah kebiasaan belajar merupakan masalah yang banyak dialami oleh siswa sehingga untuk mengefisiensikan waktu konseling kelompok dimungkinkan lebih efektif dibandingkan layanan konseling individual.

Berdasarkan uraian di atas, penulis tertarik untuk mengadakan penelitian dengan judul "Efektivitas Konseling Kelompok Melalui Teknik Self Management Untuk Meningkatkan Kebiasaan Belajar Siswa di SMP Negeri 1 Kapontori.

\section{KAJIAN TEORI}

Konseling Kelompok 
Menurut Shertzer dan Stone (dalam W.S. Winkel \& M.M. Sri Hastuti, 2007 : 590) konseling kelompok adalah suatu proses antar pribadi yang dinamis, yang terpusat pada pemikiran dan perilaku yang disadari.Menurut Winkel (2007) konseling kelompok adalah suatu proses antarpribadi yang dinamis, yang terpusat pada pemikiran dan perilaku yang disadari.

Menurut Heru Mugiarso (2007) konseling kelompok merupakan layanan konseling yang diselenggarakan dalam suasana kelompok. Materi umum layanan konseling kelompok diselenggarakan dalam kelompok yang memanfaatkan dinamika kelompok yang meliputi segenap bidang bimbingan. Masalah tersebut dilayani melalui pembahasan yang intensif oleh seluruh anggota kelompok.

Berdasarkan dari beberapa pendapat di atas, maka dapat disimpulkan bahwa konseling kelompok adalah suatu proses pemberian bantuan kepada individu dalam suasana kelompok agar mampu menyelesaikan sendiri masalah-masalah yang sedang dihadapi dengan mengembangkan kemampuan-kemampuan yang dimiliki secara optimal.

Tujuan konseling kelompok adalah memberikan bantuan kepada konseli agar mereka mampu memahami dan menerima dirinya serta mengambil keputusan sendiri atas masalah-masalah yang dihadapi yang berkaitan dengan masalah pribadi, sosial, belajar dan karir.

Ada 4 tahapan dalam proses konseling kelompok yaitu sebagai berikut :

a. Tahap permulaan (pembentukan kelompok), yaitu tahap yang dilakukan sebagai upaya untukmenumbuhkan minat bagi terbentuknya kelompok yang meliputi pemberian penjelasan tentang adanya layanan konseling kelompok bagi para siswa, penjelasan pengertian, tujuan dan kegunaan konseling kelompok, ajakan untuk memasuki dan mengikuti kegiatan, serta kemungkinan adanya kesempatan dan kemudahan bagi penyelenggaraan konseling kelompok.

b. Tahap transisi, merupakan masa setelah proses pembentukan dan sebelummasa bekerja (kegiatan). Tahap ini yang merupakan proses dua bagian, yang ditandai dengan ekspresi sejumlah emosi dan interaksi anggota.

c. Tahap kegiatan sering disebut juga sebagai tahap bekerja, tahap penampilan, tahap tindakan, dan tahap pertengahan yang merupakan inti kegiatan konseling kelompok, sehingga memerlukan alokasi waktu 
yang terbesar dalam keseluruhan kegiatan konseling kelompok.

d. Tahap pengakhiran, yaitu memberi kesempatan pada anggota kelompokuntuk memperjelas arti dari pengalaman mereka, untuk mengkonsolidasi hasil yang mereka buat, dan untuk membuat keputusan mengenai tingkah laku mereka yang ingin dilakukan di luar kelompok dan dilakukan dalamkehidupan sehari-hari.

\section{Teknik Self Management}

Menurut Suhartini dan Makhfud (2011: 33) self management adalah suatu prosedur yang menuntut seseorang untuk mengarahkan atau mengatur tingkahlakunya sendiri. Pengelolaan diri (Self management) adalah prosedur dimana indivudu mengatur perilakunya sendiri (Gantina 2011:180).

Menurut The Liang Gie (2000:77) self management berarti mendorong diri sendiri untuk maju, mengatur semua unsur kemampuan pribadi, mengendalikan kemampuan untuk mencapai hal-hal yang baik, dan mengembangkan berbagai segi dari kehidupan pribadi agar lebih sempurnah. Sedangkan menurut Astryani (2010:13) menyatakan bahwa self management merupakan suatu kemampuan untuk mengatur berbagai unsur di dalam diri individu seperti pikiran, perasaan dan perilaku, selain itu self management juga bermanfaat untuk menetapkan tujuan yang ingin dicapai dengan menyusun berbagai cara atau langkah demi mencapai apa yang menjadi dalam harapan dalam belajar mengontrol diri untuk merubah pikiran dan perilaku menjadi lebih baik dan efektif.

Dari pengertian diatas dapat disimpulkan bahwa self managment terjadi karena adanya suatu usaha pada individu untuk memotivasi diri, mengelola semua unsur yang terdapat di dalam dirinya, berusaha untuk memperoleh apa yang ingin dicapai, serta mengembangkan pribadinya agar lebih baik. Ketika individu mengelola semua unsur yang terdapat didalam dirinya yang meliputi pikiran, perasaan dan tingkahlaku, maka dapat dikatakan bahwa individu tersebut telah memiliki kemampuan self management.

Self management di perlukan bagi seseorang agar mampu menjadikan dirinya sebagai manusia yang berkualitas dan bermanfaat dalam menjalankan misi kehidupannya. Self management membuat orang mampu mengarahkan setiap tindakannya kepada hal-hal positif. Secara sederhana self management dapat diartikan sebagai suatu upaya mengelolah diri sendiri kearah yang lebih baik sehingga dapat menjalankan misi yang disusun dalam rangka mencapai tujuan. 
Manfaat self management menurut Komalasari, Wahyuni, Karsih, (2011:180) adalah sebagai berikut:

a. Membantu peserta didik untuk dapat mengelola diri baik pikiran, perasaan dan perbuatan sehingga dapat berkembang secara optimal.

b. Dengan melibatkan peserta didik secara aktif maka akan menimbulkan persaan bebas dari kontrol orang lain

c. Dengan meletakkan perubahan sepenuhnya kepada individu maka dia akan menganggap perubahan yang terjadi karena usaha sendiri dan lebih tahan lama.

d. Individu dapat semakin mampu untuk menjalani hidup yang di arahkan sendiri.

Menurut Gantina (2011), self management biasanya dilakukan dengan mengikuti langkah-langkah sebagai berikut:

a. Tahap monitor diri atau observasi diri.

Pada tahap ini siswa dengan sengaja mengamati tinglahlakunya sendiri serta mencatatnya dengan teliti. Catatan ini dapat menggunakan daftar cek atau catatan observasi. Hal-hal yang perlu diperhatikan siswa dalam mencatatat tingkahlakunya adalah frekuensi, intensitas, dan durasi tingkahlaku.

b. Tahap evaluasi diri

Pada tahap ini para siswa membandingkan hasil catatan tingkahlaku dengan target tingkahlaku yang telah dibuat. Perbandingan ini dilakukan untuk mengevaluasi efektifitas dan efisien program. Bila program tersebut tidak berhasil maka perlu ditinjau kembali program tersebut, apakah target tingkahlaku yang ditetapkan memiliki ekspektasi yang terlalu tinggi, perilaku yang ditargetkan tidak cocok, atau penguatan yang diberikan tidak sesuai.

c. Tahap pemberian penguatan dan penghapusan

Pada tahap ini para siswa mengatur dirinya sendiri, memberikan penguatan pada diri. Tahap ini merupakan tahap yang paling sulit karena membutuhkan kemauan yang kuat dari siswa untuk melakasanakan program yang telah dibuat secara kontinyu.

\section{Kebiasaan Belajar}

Menurut Aunurrahman (2010 : 185) "Kebiasaan belajar adalah perilaku belajar seseorang yang telah tertanam dalam waktu yang relatif lama sehingga memberikan ciri 
dalam aktifitas belajar yang dilakukannya". Sedangkan dalam tulisannya Asrori Ardiansyah (2011) menuliskan, kebiasaan belajar adalah keteraturan berperilaku yang otomatis dalam belajar yang dapat dilihat dan diukur dari keseringan atau frekwensi melakukan kegiatan yang merupakan kebiasaan-kebiasaan belajar yang baik dan ditunjukkan dengan indikator-indikator berikut: a) Mempersiapkan diri dalam mengikuti pelajaran; b) Memantapkan materi pelajaran; c) Menghadapi tes.

Berdasarkan pendapat-pendapat diatas dapat disimpulkan bahwa kebiasaan belajar merupakan tingkah laku yang terbentuk karena dilakukan berulang-ulang sepanjang hidup individu dan biasanya mengikuti cara atau pola tertentu, sehingga akan terbentuk kebiasaan belajar. Jadi yang dimaksud dengan kebiasaan belajar disini adalah cara-cara belajar yang palingg sering dilakukan oleh siswa dan cara atau kebiasaan belajar dapat terbentuuk dari aktifitas belajar, baik secara sengaja ataupun tidak sengaja.

Cara atau kebiasaan belajar yang baik harus dilaksanakan oleh siswa. Dengan kebiasaan belajar yang baik akan lebih bermakna dan tujuan untuk memperoleh prestasi belajar yang baik dapat sesuai dengan harapan. Menurut Nana Sudjana (2005 : 165-173) ada beberapa hal yang perlu diperhatikan dalam proses belajar, yaitu:

a. Cara mengikuti pelajaran

Cara mengikuti pelajaran di sekolah merupakan bagian penting dari proses belajar, siswa dituntut untuk dapat menguasai bahan pelajaran. Jika guru memberikan pekerjaan rumah, ajaklah teman untuk diskusi pokokpokok tugas yang diberikan.

b. Cara belajar mandiri di rumah

Belajar mandiri di rumah merupakan tugas pokok setiap siswa. Syarat utama belajar di rumah adalah keteraturan belajar yaitu memiliki jadwal belajar meskipun waktunya terbatas. Bukan lamanya belajar tetapi kebiasaan teratur dan rutin melakukan belajar setiap harinya meskipun dengan jam yang terbatas.

c. Cara belajar kelompok

Cara belajar sendiri di rumah sering menimbulkan kebosanan dan kejenuhan. Perlu adanya variasi cara belajar seperti belajar bersama dengan teman yang bisa dilakukan di sekolah, perpustakaan, dirumah teman ataupun tempat-tempat yang nyaman untuk belajar. Pikiran dari banyak orang lebih baik dari pikiran satu orang itulah manfaat belajar bersama.

d. Mempelajari buku teks 
Buku adalah sumber ilmu, oleh karena itu keharusan bagi siswa untuk membaca buku. Kebiasaan membaca buku harus dibudayakan oleh siswa lebih memahami bahan pelajaran dan dapat pula lebih tahu terlebih dahulu sebelum bahan pelajaran tersebut diberikan guru.

e. Menghadapi ujian

Keadaan yang paling mencemaskan bagi siswa adalah saat menghadapi tes, ulangan ataupun ujian. Cemas, sibuk kurang isitirahat karena mengejar belajar untuk ujian sehingga menimbulkan ketegangan psikologis yang berakibat kepercayaan diri menurun. Bagi yang sudah mempersiapkan diri dari awal, ujian adalah hal biasa. Ada beberapa hal yang sebenarnya ujian itu lebih mudah dari cara belajar atau kebiasaan belajar yang dilakukan. Oleh karena itu ujian bukan meruapkan kekhwatiran dan ketegangan melainkan sebaliknya.

Keberhasilan siswa dalam mengikuti pelajaran banyak bergantung pada kebiasaan belajarnya. Kebiasaan belajar dimulai dari cara mengikuti pelajaran, belajar mandiri di rumah, belajar kelompok, cara mempelajari buku dan sikpa dalam menghadapi ujian/ulangan/tes. Cara atau kebiasaan belajar diatas harus dimulai oleh diri sendiri dengan membiasakan diri dan mendisiplinkan diri dalam belajar. Hindari belajar dalam tempo dan kadar belajar yang berat saat akan ujian sebab kurang membantu dalam keberhasilan belajar. Kebiasaan belajar harus dimulai sejak dini kepada seorang siswa. Hal ini dimaksudkan agar siswa merasa terbiasa melakukan kegiatan belajar dalam kesehariannya.

\section{METODE PENELITIAN}

Dalam penelitian ini peneliti menggunakan pendekatan kuantitatif dengan desain Pre-Experimental dengan bentuk designOne-Group Pretest-Postest Design, yaitu suatu teknik untuk mengetahui efek sebelum dan sesudah perlakuan (Sugiyono, 2012). Sampel dalam penelitian ini menggunakan teknik purposive sampling yaitu teknik pengambilan sampel yang yang ditentukan oleh peneliti karena tujuan khusus tertentu (Sugiyono, 2012). Adapun jumlah sampel penelitian yaitu 12 siswa.

\section{HASIL DAN PEMBAHASAN}

Penelitian ini bertujuan untuk mengetahui dan mendeskripsikan kebiasaan belajar siswa dan keefektifan layanan konseling kelompok melalui teknikself management untuk meningkatkan kebiasaan belajar siswa kelas VIII SMP Negeri 1 Kapontori. Adapun deskripsi kebiasaan belajar siswa dan keefektifan 
layanan konseling kelompok melalui teknikself management untuk meningkatkankebiasaan belajar siswa dijelaskan sebagai berikut.

\section{Tabel 1. Deskripsi Kebiasaan Belajar}

\section{Siswa}

\begin{tabular}{|c|c|c|c|c|c|}
\hline \multirow{2}{*}{ Kriteria } & \multicolumn{2}{|c|}{ Pretest } & \multicolumn{2}{c|}{ Postest } & $\begin{array}{c}\text { Selisih } \\
\text { Peningkatan }\end{array}$ \\
\cline { 2 - 6 } & Frekuensi & \% & Frekuensi & \% & $50 \%$ \\
\hline Rendah & 8 & 66,7 & 2 & 16,7 & $8,3 \%$ \\
\hline Sedang & 4 & 33,3 & 3 & 25 & \\
\hline Tinggi & & & 7 & 58,3 & \\
\hline Total & $\mathbf{1 2}$ & $\mathbf{1 0 0}$ & $\mathbf{1 2}$ & $\mathbf{1 0 0}$ & \\
\hline
\end{tabular}

Berdasarkan tabel di atas dapat diketahui bahwa sebelum pemberian layanan konseling kelompok dengan teknik self management untukmeningkatkan kebiasaan belajar siswa berada pada kategori rendah yaitu 8 siswa atau66,7\% subyek dan 4 siswa atau 33,3\% subyek dalam kategori sedang dari 12 sampel penelitian. Akan tetapi setelah diberikan perlakuan, tingkat kebiasaan belajar siswa meningkat yaitu dari 12 siswa, tersisa 2 siswa atau $16,7 \%$ berada pada kriteria rendah, 3 siswa atau $25 \%$ pada kriteria sedang dan 7 siswa atau 58,3\% berada pada kriteria tinggi dalam meningkatkan kebiasaan belajarnya. Artinya terjadi selisih peningkatan yang signifikan dan baik dalam meningkatkan kebiasaan belajar. Hal tersebut memberikan pemahaman dan gambaran bahwa para siswa telah memiliki kebiasaan belajar yang baik, terkhusus pada lingkungan sekolah dan di rumah.
Berdasarkan tabel 1dapatdiketahui bahwa sebelum diberikan layanan konseling kelompok dengan teknikself management mengalami peningkatan yang signifikan. Hal tersebut menunjukkanbahwakebanyakansiswakelas VIII SMP Negeri 1 Kapontori memiliki tingkat kebiasaan belajar yang masih kurang atau secarapersentase dalamkriteria rendah, karena alasan tersebut dalam penelitianinidiberikan layanan konseling kelompok dengan maksud bahwa layanan konseling kelompok memilikifungsi dua utamayaitu (1) preventif, layanan konseling yang diarahkan untuk mencegah terjadinya masalah pada individu, dalam arti bahwa individu memiliki kemampuan normal atau berfungsi secara wajar di masyarakat tetapi memiliki beberapa kelemahan dalam kehidupannya sehingga mengganggu kelancaran berkomunikasi dengan orang lain; dan yang ke (2) kuratif, layanan konseling yang diarahkan untuk mengatasi masalah yang dialami individu. Dalam hal ini membantu individu untuk dapat keluar dari persoalan yang dialaminya dengan cara memberikan kesempatan, dorongan dan pengarahan kepada individu untuk mengubah sikap dan perilakunya agar selaras dengan lingkungannya. 
Efektivitas layanan konseling kelompok melalui teknik self management untuk meningkatkan kebiasaan belajar siswa kelas VIII SMP Negeri 1 Kapontori

Hasil analisis data sebelum perlakuan (pretest) berdasarkan tabel 1.1. diketahui bahwa tingkat kebiasaan belajar pada kriteria rendah yaitu 8 siswa atau $66,7 \%$, dan 4 siswa atau 33,3\% subyek dalam kategori sedang dari total 12 sampel penelitian. Akan tetapi setelah diberikan perlakuan melalui teknik self management, tingkat kebiasaan belajar dengan kriteria rendah mengalami selisih selisih peningkatanyang signifikan yaitu dari 12 sampel, 7 siswa atau $58,3 \%$ sampel penelitian berada pada kriteria baik, 3 siswa atau $25 \%$ kriteria sedang dan 2 siswa atau $16,7 \%$ siswa berada pada kriteria kurang baik, dengan pemberian perlakuan kurang lebih delapan kali treatmen.

Berdasarkan hasil uji paired $t$ tes setelah diberikan perlakuan dengan teknik self management menunjukkan kebiasaan belajar siswa berada pada kategori tinggi. Hal tersebut menunjukkan bahwa ada perbedaan yang signifikan antara kelompok pretest dengan kelompok posttest dengan nilai masing-masing nilai sig. (2-tailed) probabilitas 0.000 pada taraf signifikansi nilai $0.05(\mathrm{p}<0.05)$, yang berarti dapat disimpulkan bahwa layanan konseling kelompok melalui teknik self management untuk meningkatkan kebiasaan belajar siswa kelas VIII SMP Negeri 1 Kapontori yang dilakukan berhasil secara signifikan atau efektif untuk dilakukan.

Penelitian ini dilakukan pada beberapa siswa kelas VIIIC dan VIIID SMP Negeri 1 Kapontori, perlakuan yang diberikan berupa layanan konselingkelompok dengan teknik self management. Layanan konseling kelompok dengan teknik self management diberikan sebanyak delapan kali pertemuan. Setiap pertemuan peneliti memberikan materi yang sesuai dengan indikator dari kebiasaan belajar dan kegiatan diskusi kelompok dalam hal ini siswa diharapkan dapat mengelolah dirinya (teknik self management) melalui layanan konseling kelompok.

Setelah diberikan layanan konseling kelompok dengan teknik self management, kebiasaan belajar siswa dari 12sampel penelitian, mengalami peningkatan, yaitu dengan persentasi 25$58,3 \%$ subyek atau dikriteria siswa memiliki kebiasaan belajar yang baik atau tinggi. Hal ini menunjukkan bahwa setelah diberikan perlakuan berupa layanan konseling kelompok dengan teknik self management selama delapan kali pertemuan terjadi peningkatan yang signfikan yaitu dari kategori rendah meningkat menjadi kategori tinggi. Hal ini 
juga terlihat selama proses pengamatan dalam pemberian layanan bahwa setiap pertemuan siswa mengalami perubahan sikap yang baik seperti siswa mulai mengikuti pelajaran dengan baik, siswa mulai belajar mandiri di rumah, siswa sudah mulai menyukai belajar kelompok, mulai senang membaca mempelajari buku teks dan tidak khawatir dan cemas ketika akan menghadapi ujian/ulangan

Berdasarkan hasil pengamatan setelah postest, siswa mulai menunjukkan kebiasan belajar berdasarkan indikatorindikator yaitu sebagai berikut:

1) Cara mengikuti pelajaran

Setelah diberikan perlakuan layanan konseling dengan teknik self management, siswa-siswa mulai mengikuti pelajaran dengan baik, mulai mengerjakan tugas dengan berdiskusi dengan siswa lain.

2) Cara belajar mandiri di rumah Setelah diberikan perlakuan melalui layanan konseling kelompok dengan teknik self management, siswa-siswa mulai dapat mengatur jadwal belajar seperti rutin belajar setiap harinya meskipun dengan jam terbatas.

3) Cara belajar kelompok

Setelah diberikan perlakuan melalui layanan konseling kelompok dengan teknik self management, siswa sudah mulai mau diajak berdiskusi untuk mengerjakan tugas secara berkelompok, saling memberi ide, masukan, dan saran.

4) Mempelajari buku teks

Setelah diberikan perlakuan melalui layanan konseling kelompok dengan teknik self management, siswa mulai rajin membaca buku dan memahami bahan pelajaran diberikan oleh guru, siswa juga mulai rutin ke perpustakaan diwaktu yang senggang atau pada jam istirahat.

5) Menghadapi ujian

Setelah diberikan perlakuan melalui layanan konseling kelompok dengan teknik self management, kecemasan siswa mulai berkurang karena telah mempersiapkan diri jauh sebelum ujian/ulangan dalam arti bahwa siswa sudah mempelajari bahan pelajaran yang akan diujiankan sehingga siswa tidak merasakan kekhawatiran dan tegang yang berlebihan saat ujian

Adapun ditinjau dari indikatorindikatorkebiasaan belajar siswa, sebelum dan setelah diberikan perlakuan juga mengalami perubahan yaitu berupa peningkatan kebiasaan belajar yang sangat baik atau dalam persentasi dikategorikan tinggi.

Dalam penerapan teknik pengelolaan diri (self management) tanggung jawab keberhasilan konseling berada di tangan 
konseli (dalam penelitian ini adalah siswa yang menjadi sampel penelitian). Peneliti berperan sebagai pencetus gagasan, fasilitator yang membantu merancang program serta motivator bagi konseli (Sukadji dalam Komalasari, Wahyuni, Karsih, 2011:181). Dalam pelaksanaan pengelolaan diri biasanya diikuti dengan pengaturan lingkungan untuk mempermudah terlaksananya pengelolaan diri. Pengaturan lingkungan dimaksudkan untuk menghilangkan faktor penyebab dan dukungan untuk perilaku yang akan dikurangi atau ditingkatkan. Pengaturan lingkungan dapat berupa mengubah lingkungan fisik, mengubah lingkungan sosial dan mengubah lingkungan atau kebiasaan sehingga menjadi perilaku yang tidak dikehendaki hanya dapat dilakukan pada waktu dan tempat tertentu saja (Sukadji dalam Komalasari, Wahyuni, Karsih, 2011:181).

Self management di perlukan bagi seseorang agar mampu menjadikan dirinya sebagai manusia yang berkualitas dan bermanfaat dalam menjalankan misi kehidupannya. Self management membuat orang mampu mengarahkan setiap tindakannya kepada hal-hal positif. Secara sederhana self management dapat diartikan sebagai suatu upaya mengelolah diri sendiri kearah yang lebih baik sehingga dapat menjalankan misi yang disusun dalam rangka mencapai tujuan.

Berdasarkan uraian tersebut di atas menunjukkan bahwa ada perubahan yang signifikan yaitu peningkatan kebiasaan belajar siswa pada semua indikatorindikator yang diterapkan. Meskipun demikian, hendaknya perlu dikembangkan lagi terkait dengan kebiasaan belajar siswa menurut beberapa teori lain. Maka dapat disimpulkan bahwa layanan konseling kelompok melalui teknik self management efektif untuk meningkatkan kebiasaan belajar siswa kelas VIII SMP Negeri 1 Kapontori.

\section{PENUTUP}

\section{Kesimpulan}

Berdasarkan hasil analisis data dan pembahasan dalam penelitian ini, maka peneliti menarik kesimpulan sebagai berikut:

1. Pada umumnya siswa kelas VIII SMP Negeri 1 Kapontori telah memiliki kebiasaan belajar yang baik setelah diberikan layanan konseling kelompok melalui teknik self management. Artinya bahwa para siswa telah mampu menunjukkan perubahan kebiasaan belajar yaitu siswa mulai mengikuti pelajaran dengan baik seperti sebelum mengerjakan tugas, siswa saling berdiskusi terlebih dahulu, siswa sudah mampu mengatur jadwal 
belajarnya dengan rutin pada waktu yang terbatas, siswa juga mulai menyukai belajar kelompok, rutin ke perpustakaan membaca di waktu senggang dan kecemasan mulai berkurang saat menghadapi ujian/ulangan.

2. Layanan konseling kelompok dengan teknik self managment untuk meningkatkan kebiasaan belajar siswa, efektif untuk dilakukan, karena keberhasilan untuk meningkatkan kebiasaan belajar siswa tidak terlepas dari peranan siswa itu sendiri yang memiliki kemauan untuk meningkatkan kebiasaan belajarnya dan kualitas layanan bimbingan dan konseliing serta teknik yang diterapkan. Melalui teknik self management dengan 8 kali pertemuan telah mampu meningkatkan kebiasaan belajar siswa secara persentasi meningkat $25-58,3 \%$ dari 12 sampel penelitian.

\section{Saran}

Berdasarkan hasil penelitian, pembahasan, dan kesimpulan, maka peneilti memberikan saran yang diharapkan dapat bermanfaat bagi pihak lain:

1. Bagi pihak sekolah

$\begin{array}{llr}\text { Untuk guru Bimbingan dan } \\ \text { Konseling } & \text { dapat } & \text { terus } \\ \text { mengembangkan } & \text { layanan }\end{array}$

bimbingan dan konseling baik melalui layanan individu, kelompok maupun klasikal, karena dengan hal tersebut implementasi layanan bimbingan konseling kelompok pada khususnya, dapat lebih dikembangkan melalui media-media bimbingan dan konseling agar metode pemberian layanan bimbingan dan konseling kelompok lebih bervariasi.

2. Bagi peneliti selanjutnya yang tertarik untuk meneliti kebiasaan belajar dan teknik self management, untuk dapat menguji variabel lain yang lebih signifikan dan menggunakan teknik konseling yang lebih efektif.

\section{DAFTAR PUSTAKA}

Aunurrahman. 2010. Belajar dan Pembelajaran. Bandung : Alfabeta

Komalasari, G., Wahyuni, E., dan Karsih, 2011. Teori dan Teknik Konseling. Jakarta Barat: PT. Indeks

Mugiarso, Heru, dkk. 2004. Bimbingan dan Konseling. Semarang: UniversitasNegeri Semarang Press

Sugiyono, 2011. Metode Penelitian Pendidikan (Pendekatan Kuantitatif, Kualitatif dan R\&D) : Bandung: Alfa Beta

Slameto, 2003. Belajar dan Faktor-Faktor Yang mempengaruhinya. Jakarta: Rineka Cipta. 
W.S. Winkel dan M.M. Sri Hastuti. 2007. Bimbingan dan Konseling Di Institusi Pendidikan. Yogyakarta: PT. Grasindo.

Wibowo, Mungin Edi. 2005. Konseling Kelompok Perkembangan. Semarang : UNNES Press. 